\title{
Presequence Protease, Mitochondrial
}

National Cancer Institute

\section{Source}

National Cancer Institute. Presequence Protease, Mitochondrial. NCI Thesaurus. Code C131240.

Presequence protease, mitochondrial (1037 aa, $\sim 117 \mathrm{kDa}$ ) is encoded by the human PITRM1 gene. This protein is involved in the catabolism of mitochondrial peptides. 